\title{
The Tamest of Tigers? \\ Understanding Hong Kong's Innovation System and Innovation Policies
}

\author{
Naubahar Sharif ${ }^{\mathrm{a},}$, Erik Baark ${ }^{\mathrm{b}}$ \\ ${ }^{a}$ Division of Social Science, The Hong Kong University of Science and Technology, Clear Water Bay, \\ Kowloon, Hong Kong SAR \\ b Division of Social Science, The Hong Kong University of Science and Technology, Clear Water Bay, \\ Kowloon, Hong Kong SAR
}

\begin{abstract}
Using Hong Kong as a case study, this paper explicates the innovation system in a "Tiger" economy that has been less successful in making up lost technological ground than neighbouring Tiger economies. The paper outlines two important sides of Hong Kong's innovation system: its strengths, characterized by a focus on flexible linkages, learning patterns, absorptive capabilities, and exploitation of existing technology; and its weaknesses, characterized by fragmentation in its current innovation policy mix, which has adversely affected its success in innovation-intensive fields. We argue that this policy mix needs urgent remediation if Hong Kong is to pull even in introducing technology and innovation policies.

Keywords: Hong Kong; Innovation System; Innovation Policy; Newly Industrializing “Tiger” Economies; East Asia

* Corresponding author. Tel.: +852 2358 7826; fax: +852 23350014

Email addresses: sosn@ust.hk (N. Sharif); sobaark@ust.hk (E. Baark)

\section{Biographical Notes}

Naubahar Sharif is a Research Assistant Professor in the Division of Social Science, The Hong Kong University of Science and Technology. He received his PhD degree from the Department of Science and Technology Studies (S\&TS) at Cornell University. In his current research program he is investigating the history of the innovation systems concept within a broader sociology of technology framework and applying the empirical results of his research to Hong Kong.

Dr. Erik Baark is Associate Professor in the Division of Social Science, Hong Kong University of Science and Technology. He received his $\mathrm{PhD}$ degree in Information and Computer Science from the University of Lund in 1986, and was awarded a Dr.Phil. degree at the Faculty of Humanities, University of Copenhagen, in 1998. His primary interests include conducting comparative studies of the interaction between technology and culture with special emphasis on China and other East Asian countries, and analyzing the role of innovation in service industries, with a focus on the engineering consultancy sector.
\end{abstract}




\section{Introduction}

Since its formal introduction in the 1980s, the innovation systems approach has come to be widely used both in academic contexts and as a tool for policymaking. ${ }^{1}$ This trend is reflected in the innovation systems (IS) literature, which focuses on the analysis of ISs in developed countries of the West as well as in several of the rapidly developing "Tiger" economies. Within the glow of this spotlight on the Tiger economies, however, Hong Kong has been conspicuous by its absence. Conversely, principal attention has been given to Korea, Taiwan, and Singapore (see, for example, Hou and Gee 1993; Kim 1993; Wong 1996; Chung 2001; Wong 2003; Chang and Shih 2004), all of which are examples of successful catch-up, Tiger economies that have implemented aggressive science, technology, and innovation policies, combined with intensive technological learning.

Using Hong Kong as a case study, this paper describes, analyzes, and critiques the innovation system in a Tiger economy that has been less successful in making technological progress than others. ${ }^{2}$ In contrast to these countries in particular, and developed countries in general, Hong Kong has demonstrated over the past decade that it possesses neither the dynamic technological capabilities in its traditional industrial sectors nor the expertise in orthogonally new "high-tech" industries to move forward in a fashion that can successfully accommodate scientific, technological, and innovation-led growth. To be sure, since the Asian Financial Crisis of 1997 and the deep-rooted recession that followed it (HKSAR, 1999), the Hong Kong government has made an intensive_-but arguably misguided—effort to promote a mode of innovation that would fuel growth (cf. Baark and Sharif 2006 [forthcoming]). On the one hand, this effort on the part of the government has merely highlighted the 
weaknesses in Hong Kong’s innovation system by exposing the inadequate and fragmented nature of its resources. On the other hand, such measures have also, ironically, brought the traditional strengths of Hong Kong’s innovation system back into play.

Based on original fieldwork—including interviews with key policymakers and advisors_-conducted by the authors in Hong Kong, this paper illuminates two important sides of Hong Kong’s innovation system. First, we highlight the strengths of Hong Kong’s innovation system, which support a mode of innovation characterized by a focus on flexible linkages, learning patterns, absorptive and recombinative capabilities, and exploitation of existing knowledge. Second, we address the weakness and fragmentation of Hong Kong’s current innovation policy mix, which has adversely affected Hong Kong’s success in innovation-intensive fields such as information technology and bio-technology. We argue that this policy mix needs to be remedied urgently if Hong Kong is to make up for lost time in introducing technology and innovation policies.

From a scholarly standpoint, this paper argues that studies of innovation systems such as Hong Kong's should accord as much consideration to the 'soft' side of innovation systems_-as embodied in activities that involve learning by doing, using, and interacting — as to the 'formal' side—as embodied by activities that involve traditional development channels fuelled by scientific research and technological research and development (R\&D). At a policy level, we call on the Hong Kong government to make technology and innovation policy an integral part of overall central policy and we advocate institutional reform in the present bureaucratic structure of the government. 


\section{Main Trends in the History of Hong Kong's Innovation System}

To understand the contours of current innovation in Hong Kong as fully as possible, it is instructive to trace the precarious route to industrialization and economic modernization that has characterized the territory's development.

Early Twentieth Century: Studies of Hong Kong's economic development in the early part of the twentieth century have shown that several informal institutions and state initiatives have supported industrialization. Hong Kong grew an industrialized economy by relying primarily on small-scale manufacturers linked in familial or ethnic networks, connected with expanding markets for relatively low technology products in China, South East Asia, and Europe/United States (Clayton 2000). Recognizing the existence of this ‘undergrowth’ sector of small-scale industrial firms in Hong Kong is important, however, for two reasons. First, it provided opportunities for Chinese entrepreneurs to accumulate technical and managerial skills that could be successfully deployed in subsequent stages of development; second, it created opportunities through which Chinese firms could practice organizational modes that supported networking, sub-contracting relationships, and an international search for markets-elements that 'rehearsed' critical features of later industrialization in Hong Kong that remain prevalent to this day.

Cold War Period-1950s to 1970s: The overthrow of the Kuomintang (KMT) regime of General Chiang Kai Shek in 1949 by the current government of the People’s Republic of China remains one of the most significant events in Hong Kong's history. 
It precipitated an exodus of about one million Mainland Chinese to Hong Kong. The people of Hong Kong, including its migrants, therefore grew up and developed in a community that had Chinese roots, but were under British administration. These migrants, in turn, established increasingly large-scale manufacturing industries, further expanding Hong Kong's role beyond that of an entrepôt. In the face of the declining power of the KMT in China, the Shanghai textile barons, among other parties, transferred enormous amounts of capital and managerial expertise in textile manufacturing to the colony (Wong 1988). Today, it is estimated that more than half of Hong Kong’s seven-million-plus citizens are descendents of post-1949 migrants.

Opening of China-1980s and 1990s: Two landmark events in the 1980s period deeply affected Hong Kong's people and its innovation system. The first was the modernization program that the late Chinese leader Deng Xiaoping promulgated in 1978. The second was the initiation of discussions between the Chinese and British governments that opened in 1982 over the future sovereignty of Hong Kong. The latter negotiations ended in 1984 with the signing and ratification of the Sino-British Joint Declaration, which stated that Hong Kong (HK) would become a Special Administrative Region (SAR) of the People's Republic of China and that Hong Kong's capitalist system and 'way of life' would be preserved for 50 years. The 'one country-two systems’ framework under which Hong Kong is presently governed was enshrined in the 'Basic Law', the present constitution for the HKSAR.

Deng's modernization program acted as a catalyst in the transformation of Hong Kong’s innovation system. In many ways, the opening of China precipitated and accelerated Hong Kong's movement up a steep learning curve. This ultimately proved helpful, not just economically, but also in persuading the people of Hong 
Kong that their fate and future lay with Mainland China. The most striking change in Hong Kong's innovative landscape that was triggered by the opening of the Mainland in 1979 was the decreasing role of manufacturing in Hong Kong and the simultaneous rise in the services sector. At its peak in the mid-1980s, the manufacturing sector employed 41.7 per cent of the active labour force but by 1995 it employed only 15.3 per cent (Berger and Lester 1997: 9). In contrast, the service sector's share in Hong Kong's GDP grew from 67 per cent in 1980 to 87 per cent in 2002.

From Crown Colony to Special Administrative Region: The salient development of the 1990s and beyond was the return of the British Crown Colony of Hong Kong to the People’s Republic of China. Enright et al. (1997: 7) accurately describe how Hong Kong’s historical role as a city of departure from China laid the foundation for a reverse flow of business investments during the 1990s not only back to Hong Kong, but to Mainland China through Hong Kong. They claim that this has "helped Hong Kong become the de facto capital of the 50 million or more overseas Chinese who today play such an important role in the economic modernization of the Asian region and in the reconstruction of China's market economy.” The economic impact has been considerable, since overseas Chinese investors_often Hong Kong companies or investors operating out of Hong Kong-now employ 14-15 million people in China.

Furthermore, the migration of production facilities to the PRD has in many ways represented growth, rather than decline, in Hong Kong's engagement in manufacturing; for political reasons such growth was however categorized as outside the territory, even if it was, from a historical perspective, a reintegration into Chinese markets. The effect of the reintegration of Hong Kong on the service industries must also be seen as beneficial in the sense that most of the migration spurred further 
growth and increased sophistication in producer business services (Tao and Wong 2002). In establishing and upgrading these networks, Hong Kong firms have exploited their traditional strategies of imitation and followership, while emphasizing the development of organizational know-how rather than formal R\&D for new products.

\section{Formal Research and Development in Hong Kong's Innovation System}

R\&D intensity in Hong Kong has been growing (measuring R\&D as a percentage of GDP), but not dramatically (in comparison with other countries having a similar GDP per capita), at a rate of 0.60 per cent in 2002. Statistical data for R\&D expenditures was not systematically collected in Hong Kong until the mid-1990s (see Table 1).

[TABLE 1 HERE]

Over the period for which figures are available, higher education R\&D (HERD) constituted well over half (60 per cent or more) of total R\&D, followed by firms (BERD) and then the government sector (GOVERD).

Higher education R\&D activities are governed by the University Grants Committee (UGC), a government-appointed body that funds the eight institutes for higher education in Hong Kong. In 2000 and 2001 a negligible amount of HERD (less than 1 per cent of the total amount) was carried out by parties from outside of Hong Kong. It can therefore be said that, effectively, all HERD activity in Hong Kong is funded by and conducted by domestic actors. There are no figures available for the breakdown of $\mathrm{R} \& \mathrm{D}$ expenditures between domestic and foreign actors in the business 
sector, despite cases of foreign firms such as 3M and Motorola known to conduct R\&D activities in Hong Kong. In any event, such activities can be assumed to be small in scale because of the relatively small technological advantages Hong Kong can provide. Therefore, although globalization has always been a factor because of the high degree of internationalization in Hong Kong, it is not deemed to be an important force determining the pattern of R\&D spending.

Along with other statistical indicators pertaining to science and technology, data on patents can be used as a performance indicator of $R \& D$ output. There are two types of patents in Hong Kong, the standard patent and the short-term patent. Subject to payment of a renewal fee, a standard patent in Hong Kong has a term of protection of up to 20 years, whereas a short-term patent has a maximum term of eight years. The number of patent applications increased from 1,092 in 1991 to 9,226 in 2001 (Table 2), representing an annual growth rate of 24 per cent (HKSAR, Census and Statistics Department, Science and Technology Statistics Section 2003). ${ }^{3}$

\section{[TABLE 2 HERE]}

Another R\&D output measure is research output that is not directly related to teaching from the eight higher education institutions in Hong Kong. ${ }^{4}$ Since 1997, research output has been above 20,000 studies annually (Table 3).

\section{[TABLE 3 HERE]}

With respect to the pattern of scientific and technological specialisation, this can be discerned for the Higher Education sector only. Yet as HERD constitutes such 
a large proportion of overall GERD—well over 60 per cent—it can reflect a fairly accurate and complete picture. Most of the expenditure for the higher education sector from 1998 to 2002 is in the fields of physical sciences (between 23 per cent and 25 per cent), engineering and technology (between 23 per cent and 22 per cent), and medicine, dentistry and health (between 18 per cent and 19 per cent). The fields of arts and humanities as well as social sciences each have a 10 per cent share.

Countries with a per capita GDP that is comparable to Hong Kong's spend 1.5 per cent - 3 per cent of GDP on R\&D; Hong Kong has therefore often been dismissed as the 'odd-one-out' among the successful Asian Newly Industrialized Economies (see, for example, Lall 1996). The low level of formal investments in R\&D has also been lamented by consultants engaged by Hong Kong to identify new directions for economic development. For example, a high profile team of American academics who produced the influential report Made by Hong Kong (Berger and Lester 1997) advocated that a more serious effort to raise R\&D investments was necessary for future competitiveness.

Recent economic issues, in particular the Asian Financial Crisis that began in 1997, have also had a lasting effect on Hong Kong’s innovation system. The Crisis contributed to a dramatic bursting of the asset bubble that underlay much of Hong Kong's economy and triggered the territory's most acute economic recession. As a result, Hong Kong is no longer able to rely on its traditional methods of accruing wealth (serving as a niche for the trading of Chinese goods, and asset inflation). Additionally, China itself has been changing dramatically. With economic liberalization gaining pace there, and with its accession into the World Trade Organization, there is less need to conduct trade through Hong Kong. In combination, 
these two factors have forced Hong Kong to find a new role for itself and a new engine for economic growth.

In response to these conditions, the Hong Kong Special Administrative Region (HKSAR) government formed, in 1997, the Commission on Innovation and Technology (CIT). As the CIT was of the opinion that "there is a weak R\&D culture in industry” (HKSAR 1999), it sees Hong Kong adapting to a new role explicitly through science, technology, and innovation. Based on the commission’s recommendations, the Hong Kong government has instituted measures to increase the amount spent on R\&D, beginning in the year 2000. Most notable among these measures was the establishment of the 'Innovation and Technology Fund' (ITF), set up with $\mathrm{HK} \$ 5$ billion earmarked to support projects that contribute to innovation and technology upgrading in industry, as well others essential to the upgrading and development of new industries. The CIT reports also laid the groundwork for a reorganization of the Industry Department into the Commerce and Industry Bureau and, in January 2000, the Applied Science and Technology Research Institute (ASTRI). ASTRI's role is conceived of as solving the problem of moving ideas from academia to industry. ${ }^{5}$ Continuing in the spirit of the CIT's recommendations, in 2000 the Innovation and Technology Commission (ITC) was set up with a mission to spearhead Hong Kong’s drive to become a world-class knowledge-based society.

The ITC manages the Innovation and Technology Fund (ITF) and the Applied Research Fund (ARF) and supports such infrastructure projects as the Hong Kong Science Park. The Hong Kong Science Park provides an environment in which to nurture clusters making sustainable land or buildings for lease available to technology-based enterprises to carry out R\&D work. ${ }^{6}$ Meanwhile the ARF is a government-owned venture capital fund established to support technology ventures 
and $R \& D$ projects that have commercial potential, with the long-term aim of increasing technological capability and enhancing the competitiveness of local industry (thereby promoting high value-added economic development in Hong Kong). ${ }^{7}$

\section{Hong Kong's Organic Innovation Patterns: Specialization, Imitative Flexibility, and Orchestration Capabilities}

As is evident from an analysis of traditional R\&D output measures, Hong Kong emerges in a negative light when evaluated according to the usual innovation criteria. Over-emphasis on R\&D input and output data can however be misleading in Hong Kong. By focusing solely on the ‘top' (inputs) and 'bottom' (output) levels of the innovation system, the important processes that occur in the 'middle' of the system tend to be overlooked, or at most are subject to rather superficial measurement. ${ }^{8}$ Innovative activity arguably is more than just a matter of producing easily measurable new knowledge (in terms of patents, for example). In Hong Kong's case, innovative activity also means recombining knowledge, selecting new knowledge, and using new knowledge effectively (with existing knowledge) to exploit opportunities. These processes deserve adequate and equal attention as they are just as important as the inputs into and outputs out of the innovation system.

It is possible to identify three dimensions or sets of characteristics that form a framework within which to represent primary innovative approaches that fall under the rubric of organic innovation systems analysis that this paper advocates. Such a framework is important for understanding innovative activity in small, developing economies, such as Hong Kong’s. They include: 
1. Absorptive capacity from global knowledge sources, adaptation of technology, recombinative capabilities for synthesizing knowledge into new productive configurations.

2. Learning from advanced customers and markets; agile sensitivity to changing demand, imitative speed/creative imitation.

3. Organizational flexibility, orchestrating loosely coupled networks and business processes; quality control.

We provide brief illustrative examples from two industries-electronics and garments_-and from Hong Kong’s widely acclaimed services sector to exemplify the primary innovative approaches that highlight the importance of the organic approach. Each of these two industries and the services sector exhibit qualities that are relatively difficult to describe in formal scientific terms or by reference to technology statistics and quantitative indicators.

\subsection{The electronics industry: high absorptive capacity and adaptive capabilities}

The speed to market and flexibility of manufacturers has time and again proven essential to the success of Hong Kong firms. One example of this phenomenon was provided during the 'Tamagotchi’ craze in 1996-1997. In 1996, the Japanese firm Bandai Co. had invented a small electronic toy, containing a relatively advanced integrated circuit and software, called a Tamagotchi (which roughly translates as 'a cute little egg'). This toy featured a game with a small virtual pet animal that required regular feeding and attention to avoid 'dying.' This virtual pet toy developed into a market frenzy almost overnight, with sales of more than five million during the first 
six months. The craze came as a surprise to Bandai, which had geared up production on a relatively small scale in Japan and was waiting to set up a manufacturing site in China. During this short interval, Hong Kong manufacturers capitalized on the overwhelming demand for Tamagotchis, which were in short supply in both Japan and the US, and developed low-cost imitations or clones, such as Melko Chick or Pocket Dino, that were produced by a network of sub-suppliers in South China. During the relatively short cycle of this particular toy craze, Hong Kong suppliers were able to reap substantial profits despite very intense price competition, and when Bandai finally managed to get their new production facility in China under steam, the market had been swarmed by imitations — from other production facilities in China— and the company in the end faced losses incurred when it had to liquidate its excess stock.

Hong Kong companies that had participated in the production of Tamagotchis or supplied components such as LCD screens to these virtual pet toys later began developing other products that exploited their extensive capacity for low-cost production. The example of the LCD industry in Hong Kong illustrates the positive aspect of the dominant strategy of Hong Kong firms. These firms emphasize market intelligence and a keen market sense in order to be able to enter the right market niches at the right time. Coupled with great manufacturing flexibility and the recombination of knowledge into new designs or new productive configurations, Hong Kong LCD firms have been able to utilize available capital and labour to expand—and shift—production with astonishing speed. These firms have responded to competitive pressures by finding a niche, moving into space left behind by more powerful competitors, and avoiding head-to-head competition. More importantly, 
Hong Kong firms have managed these moves on their own, without significant support from public institutions (Chiu and Wong 1998). ${ }^{9}$

4.2. The garments industry: organizational flexibility, orchestration capabilities and learning from advanced customers and markets

In the garment industry the technology that Hong Kong firms have accumulated and developed over the years supports their capabilities for managing human resources, operations, and suppliers. In particular, Hong Kong firms have emphasized the adaptation of production technology and design to available resources, and the recombination of knowledge related to production design, requirements of clients, and swift reconfiguration of production facilities. These skills are essential to the success of Hong Kong firms in selling to buyers in the demanding, fashion-oriented markets of advanced industrial economies. Such capabilities, while not particularly R\&D intensive, may indeed be supporting the kind of soft managerial technology that is as strongly needed in the Chinese Mainland as any other form of technology (Thompson 2003: 94-95).

The transfer of skills and capabilities from Hong Kong garment firms to increasingly competitive Chinese firms indicates the true importance of the innovative capabilities that the Hong Kong firms possessed when they moved production to the Chinese Mainland.

In their strategies for international competitiveness, Hong Kong firms have increasingly targeted niche markets for products that are time-sensitive and influenced by fashion cycles, such as garments, fur, handbags, toys, etc. These types of markets allow them to exploit their knack for opportunistic entrepreneurship and agile 
sensitivity to changing demand. Although they have often relied on conceptual design obtained from major fashion houses - either through outsourcing orders or by direct imitation - they have often successfully employed their own competence in areas such as detailed design, production flexibility, and adaptation to local resource constraints. The garment industry in Hong Kong has also deftly exploited business opportunities created by the quota system under the Multi-fibre Agreement that created an 'artificial layer' of high profits between the labour-intensive layer of production units and the high value-added layer of information-intensive and flexible production activities (Loo 2002). ${ }^{10}$

\subsection{Innovation patterns in Hong Kong's services sectors}

The expansion of high value-added clusters of service industries such as logistics, legal and financial services, or market research in Hong Kong in recent years has been grounded in the development and re-location of a range of light industries. In establishing and upgrading these networks, Hong Kong firms have exploited their traditional strategies of imitation and followership while emphasizing the development of organizational know-how rather than formal R\&D for new products. In general, service industries have tended to conduct less formal R\&D, relying on secrecy or copyright rather than patents to protect intellectual property and innovations. ${ }^{11}$ Given the relocation of manufacturing activities of Hong Kong firms to the Chinese mainland or Southeast Asian countries, services are now contributing

more than 85 per cent of the value-added in the Hong Kong economy. A study by Tao and Wong (2002) that analyzed the emergence of producer services (business services that are directly associated with the production or distribution of goods) in Hong 
Kong indicates that the growth of these services is closely related to the growth of foreign direct investment from Hong Kong to the Chinese Mainland, and with the growth rates of Hong Kong's re-exports of goods from the mainland. Such producer services now contribute 50 per cent of real GDP in Hong Kong. The relocation and expansion of producer networks from Hong Kong to the Pearl River Delta has, in other words, supported the development of important producer services such as financial services, insurance, communication, and logistics in Hong Kong. ${ }^{12}$

Consequently the innovative character of Hong Kong's services is not adequately reflected in the available R\&D statistics. The producer services offered by Hong Kong firms have been constantly improved in terms of quality, reliability, and innovative solutions during the last two decades and, despite the relatively high costs of qualified labour, Hong Kong-based service firms specialising in logistics, telecommunications, and financial services have remained competitive in the region. Trans-national service firms make up a substantial portion of the service sector, and these firms have often brought the latest technological advances to Hong Kong. But an increasing share of service firms originates in Hong Kong and has been adopting IT-based systems aggressively to innovate upon their line of service products offered and to improve the effectiveness of service delivery.

To be sure, innovations in Hong Kong’s services are not unique to Hong Kong. Many characteristics portrayed above are similar to characteristics in other service sectors. However because the service industry occupies such a large proportion of the overall economy, innovation in services is all the more relevant and important to consider. 


\section{Strengths and Weaknesses of Hong Kong's Innovation System and Policies}

\subsection{Strengths and weaknesses of Hong Kong's innovation system}

The analysis presented above suggests that Hong Kong has a weak innovation system, particularly if innovation is defined rather narrowly in terms of knowledge creation through R\&D inputs and patentable technology as output. The Hong Kong experience also however demonstrates how important it is to call attention to the exploitation of existing knowledge. Therefore, an element of strength in Hong Kong's innovation system is the ability to absorb proven technology and carry out incremental improvements in products (especially production or organization processes) that will provide competitive assets in terms of cost and flexibility of supply to global markets. A key component of this strength is a function of the capabilities of Hong Kong firms for organizing or servicing global production chains that are deeply integrated with other sectors in the Greater China region. These strengths of Hong Kong's innovation system are most clearly observed in a few specialised sectors that are usually considered low-tech, such as textile or garment products and watches. But they also characterize several service sectors that have become prominent during the last couple of decades, such as financial services, logistics, or management consulting and accounting services.

It is also however evident that the relatively low capacity of systems and organizations to create new knowledge — and thus to develop more R\&D-intensive products and services_-poses a critical challenge for future economic development in the territory. Due to a decade of investment in higher education, universities in Hong Kong have upgraded research facilities and capabilities, and they are endeavouring to 
extend their networks to private industry and service sectors in order to commercialize potential new technologies. The university sector is likely to be the main public actor in the innovation system, even if current initiatives are likely to increase the number of government-sponsored research institutes serving specific sectors. Another important trend is that an increasing source of input for innovation in Hong Kong will be $R \& D$ carried out in organizations on the Chinese Mainland. Maintaining crucial linkages to global networks, Hong Kong firms will increasingly be able to leverage their access to China's growing resources for innovation and thus seek to overcome the relative weakness of local $R \& D$ organizations.

\subsection{Evaluation of innovation policy pursued}

In evaluating past innovation policies in Hong Kong, the most salient point is how 'late' the policies have been in their introduction. Not until 1999 did Hong Kong develop any kind of formal, coordinated innovation policy. Against almost any comparison benchmark - whether in Organisation for Economic Cooperation and Development (OECD) countries, Asian Tiger economies, or countries of a similar size — that is far too late. In Hong Kong's case, this delay has arguably been especially detrimental to the overall innovation system because of the speed and intensity with which the People's Republic of China—the one economy which Hong Kong uniquely depends on most for its economic livelihood—has been opening since 1979.

The consensus among key policy advisors in Hong Kong is that a major weakness in innovation policymaking has been the low degree to which systemic relationships among the different policy areas have been addressed. Aligned with this is the low level of policy coordination. Despite the establishment of the Innovation 
and Technology Commission in 1999, for example, there remain a number of other policymaking bureaus connected with innovation, including the Commerce, Industry and Trade Bureau (CITB), the Financial Services Branch (for financial innovations), and to a lesser extent regulatory bodies such as the Telecommunications Authority or the Television and Entertainment Licensing Authority, not formally connected in terms of their functions and missions.

Partly because of Hong Kong's procrastination in tackling, introducing, and implementing innovation policy, and partly because of the sheer variety of different measures introduced, a characteristic feature of policy measures in Hong Kong is that they have been extremely fragmented. In response to this, policymakers have recently attempted to adopt an innovation systems framework in their latest policy documents so as to achieve a higher degree of coordination and integration in policy measures (HKSAR, Innovation and Technology Commission 2004).

This analysis must nevertheless be tempered by the observation that steps taken towards greater coordination and integration among the constituent elements of Hong Kong’s innovation system are nascent. There is a long way to go. The overriding and most widely expressed fear in Hong Kong remains that the bureaucratic and policy changes may, ultimately, come too late to make a positive difference. In Hong Kong’s case, the question then becomes not so much whether innovation policy has been successful: Innovation policy has not been implemented in a sustained and concentrated fashion for a long enough period to permit such an evaluation. Rather, the more relevant question for Hong Kong becomes whether it is (a) currently pursuing the correct path and (b) doing so swiftly enough. Although the answer to the first part of the question can be 'yes', there is a distinct sense of uncertainty and concern pertaining to the answer to the latter half of the question. 


\subsection{Future innovation policy}

Having considered the current state of innovation and technology development in Hong Kong and the issues and challenges before it, the Innovation and Technology Commission (ITC) of the HKSAR government has recently proposed a new strategic framework to enable the sustainable development of its innovation and technology programme, based on five elements: ${ }^{13}$

(i) Focus: to identify key technology focus areas where HK is deemed to have an advantage for making the optimal use of resources to create greater impact;

(ii) Market Relevance: to adopt a demand-led, market-driven approach in driving the innovation and technology programme to ensure investments are relevant to industry and market needs;

(iii) Industry Participation: to closely involve the industry in defining the focus areas and in other stages of innovation and technology development;

(iv) Leverage on the Mainland: to utilize the production base in the Greater Pearl River Delta region as the platform for developing applied R\&D and commercialization of applied R\&D deliverables;

(v) Better Coordination: to strengthen coordination among various technologyrelated institutions and industries for enhanced synergy and impact.

To implement this strategy, priority is given to the identification of 13 technology focus areas in order to ensure that resources are not spread too thinly over too many areas. The Hong Kong government believes that these focus areas, some of which are industry-based while others are related to specific technologies or 
applications, feature the greatest competitive edge (e.g., research strength, a strong industry base) and the strongest potential for meeting market needs (e.g. demand for new products, new or emerging technologies or technology upgrading).

Design is also considered a core element in the innovative process, in particular when facilitating industries that move up the value chain by switching their mode of production from original equipment manufacturing (OEM) to original design manufacturing (ODM) and then to original brand manufacturing (OBM). Given the diversity of design disciplines and the multi-disciplinary nature of design processes, the government's position is that the promotion of design should fall under a separate initiative.

To ensure that applied R\&D efforts will be driving towards the focus areas in future, the Innovation and Technology Fund (ITF) will adopt a new funding approach as well. Instead of funding small, diversified projects, ITF resources will be used mainly in supporting the establishment and development of R\&D centres to address particular focus areas. Other projects falling outside the focus areas will still be considered but will be funded only if they can demonstrate exceptional merit. Moreover, the Applied Research Fund (ARF) will also refer to the focus areas more closely in determining its future investments.

Although the proposed set of policy initiatives may seem elaborate, the available budget allocation for these measures from the remaining ITF funds (about HK\$3.5 billion) is not known. Furthermore, there remain questions about how many and which of the areas will be funded by the government. Some have suggested that perhaps three or four focus areas may be selected in a 'first phase' with further focus areas selected based on the success of the initial group of funded focus areas. Uncertainty also surrounds the R\&D Centres, as they may be physical centres or 
'virtual' centres. A final but significant problem is how best to approach development across the border in Southern China. While Hong Kong has made it a point to 'leverage the Mainland', many observers are concerned that it is quickly falling behind the Mainland. This means that Hong Kong may become isolated unless its acts on its advantages quickly. Indeed, there are those who argue that Hong Kong has already missed the boat in terms of taking advantage of the Mainland's production base.

\section{Discussion and Conclusions}

\subsection{Main activities influencing innovation in Hong Kong’s innovation system}

Our analysis suggests that the Hong Kong SAR's innovation system is relatively underdeveloped and undergoing an important transition. Hong Kong is a small territory; the diversity and institutional range of its innovation system compares poorly to those of other small countries or territories such as Singapore or Switzerland. Hong Kong now contends with the historical phenomenon of being a territory that has experienced relatively little government intervention while serving primarily as a trading post.

Among the specific assets of Hong Kong's innovation system is the relatively dynamic commitment of its higher education sector to innovation. University research in Hong Kong is of a high quality in comparison with that of its neighbours in the region (as indicated by research output), although recently proposed budget cuts have yet to take effect in this part of the system. Increasing interaction with industry (in 
terms of technology and research transfer) has been an important policy-initiated trend in this area over the past few years.

In firms, the commitment of resources to $R \& D$ and innovation has been increasing over the past several years. This is due in large part to the recent government initiatives. As Hong Kong firms face limits in achieving profitmaximization through cost-reduction, they are increasingly looking towards innovation and $R \& D$ to drive future profits. Combined with the incentives the government is providing, it is expected that business R\&D expenditures will continue to rise over the coming decade.

One has the impression, when analysing innovation in Hong Kong, of a system that is in its infancy from a structural point of view but is attempting to grow quickly in this regard. For this reason, performance is gaining momentum but the ability to maintain the forward drive will depend on the continued emphasis that the government places on the importance of R\&D and innovation. Hong Kong’s innovation system is also one in which the specific pattern of specialisation (in services) plays an important role. With increasing integration with the Mainland, however, it is expected that Hong Kong will be able to leverage the Mainland's strengths in order to develop innovation and R\&D strength in manufacturing (even though most manufacturing has moved north into the Pearl River Delta region of China). Because of the open nature of Hong Kong's economy, globalization vis-à-vis China is also likely to play a large role.

As researchers, we believe that, without applying a broad and organic concept of innovation to these issues, it is too easy to miss the apparent strengths of Hong Kong's innovation system by focusing too narrowly on its glaring weaknesses. The Hong Kong case demonstrates how important such organic aspects of innovation have 
been to economic growth and sustained competitiveness in market niches such as watch manufacturing — even without substantial utilitarian investments in R\&D. In other words, by shifting the focus away from formal R\&D indicators, it is possible to identify certain characteristics that can be said to have provided Hong Kong's innovation system what (little) strength it possesses.

\subsection{Policy implications}

In practice, many science and technology policies in Hong Kong remain piecemeal, with insufficient attention given to fostering interactions and spillovers at the national and international levels. In order to correct this feature, a few concrete policy implications can be drawn from the experiences of Hong Kong that may be useful for other developing countries that find themselves in a similar situation.

For the most part, governments address current challenges with administrative structures and policy instruments that have been shaped by responses to past problems. In Hong Kong, this general characteristic of policymaking becomes doubly problematic because of the virtual absence, until very recently, of coherent innovation policies. This paper argues that the very newness of policy initiatives can be made into a strength. To do so requires not only intervening in the technology arena to address market failure, but also intervening more broadly to address systemic failures that block the functioning of innovation systems, hinder the flow of knowledge and technology, and consequently reduce the overall effectiveness of R\&D efforts.

In general terms, the Hong Kong government needs to play an integrating role in managing knowledge on an economy-wide basis by making technology and innovation policy an integral part of overall central policy. New approaches or 
institutional arrangements, including public/private partnerships, may be needed to coordinate the formulation and implementation of policies. Better techniques and institutional mechanisms are also needed to improve decision-making across traditional administrative competencies and can spur innovation in government. At a more specific level, if the Hong Kong government has aspirations to intervene effectively in the innovation system, institutional reform of its bureaucracies is needed. Bureaucracies should on the one hand be competent in managing the intricate features of specific technologies and technology policy-making but also, on the other hand, be sufficiently insulated from political pressure and adequately supported by the highest ranks of the political hierarchy. Only then can favourable cooperation be cultivated among the constituent elements of the innovation system. The need for dedicated and capable government officials cannot be overstated given the rapidity of the changes that are occurring as a result of globalizing pressures on Hong Kong, especially with regard to technologically specific sectors. In addition to attracting competent civil servants, independence in formulating policy, combined with the requisite power to implement the same policies, must be accorded. Despite the embryonic status of Hong Kong's innovation policies, this should not deter the implementation of 'risky’ policy measures. Given the appropriate framework, perhaps even a culture of 'failure' may have to be tolerated both in the government and on the part of the local population (as represented by the legislature). 


\section{Acknowledgements}

The authors gratefully acknowledge the constructive comments and suggestions from discussants Jon Sigurdson and Yi Wang and participants at the $2^{\text {nd }}$ GLOBELICS Conference, 2004, 'Innovation Systems and Development: Emerging Opportunities and Challenges’, Beijing, China, 16-20 October, where an earlier version of this paper was presented. The corresponding author also acknowledges financial support from the Mario Einaudi Center, 2003-2004, 2004-2005, and in particular the 'Lam Family Award for South China Research', East Asia Program, Cornell University, 2003-2004.

\section{References}

Baark, Erik, and Naubahar Sharif. 2006. Hong Kong's Innovation System in Transition. In Asian Innovation Systems in Transition, edited by B.-Å. Lundvall, P. Intarakumnerd and J. Vang: Palgrave [forthcoming].

Berger, Suzanne, and Richard K. Lester. 1997. Made by Hong Kong. Hong Kong: Oxford University Press.

Chang, Pao-Long, Hsin-Yu Shih. 2004. The Innovation Systems of Taiwan and China: A Comparative Analysis. Technovation 23.

Chiu, Stephen W. K., and Wong Ka-Chung. 1998. The Hong Kong LCD Industry: Surviving the Global Technology Race. Industry and Innovation 3 (1):51-71. . 2001. Growth without Catching Up: Organizational Dynamics and Restructuring of the Electronics Industry in Hong Kong. In Hong Kong Institute of Asia-Pacific Studies Occasional Paper Series No.115. Hong Kong.

Chung, Sung Chul. 2001. The Research Development and Innovation System in Korea. In Research and Innovation Policies in the New Global Economy, edited by P. Larédo, Philippe Mustar. Cheltenham: Edward Elgar.

Clayton, D. V. 2000. Industrialization and institutional change in Hong Kong. In Asia Pacific Dynamism, 1550-2000, edited by A. J. H. Latham and H. Kawakatsu. London; New York: Routledge.

Enright, Michael J., Edith Elizabeth Scott, and David Dodwell. 1997. The Hong Kong Advantage. Hong Kong; New York: Oxford University Press.

HKSAR. 1998. Commission on Innovation and Technology First Report. Hong Kong. 1999. Commission on Innovation and Technology Second Report. Hong Kong.

HKSAR, Census and Statistics Department, General Statistics Section (1) B. 2003. Hong Kong Annual Digest of Statistics 2003 Edition. Hong Kong SAR. 
HKSAR, Census and Statistics Department, Science and Technology Statistics Section. 2001. In Hong Kong Monthly Digest of Statistics - July. Hong Kong SAR.

2003. Government Funding of R\&D, Innovation and Technology Upgrading, 1995/96 - 2001/02. In Hong Kong Monthly Digest of Statistics - July. Hong Kong SAR.

2003. Patent Statistics for Hong Kong, 1991-2002. In Hong Kong Monthly Digest of Statistics - January. Hong Kong SAR. . 2004. Research and Development Statistics of Hong Kong, 1998-2002. In Hong Kong Monthly Digest of Statistics - May. Hong Kong SAR.

HKSAR, Innovation and Technology Commission. 2004. New Strategy of Innovation and Technology Development. Hong Kong.

Hou, Chi-Ming and San Gee. 1993. National systems supporting technical advance in industry: the case of Taiwan. In National Innovation Systems: A Comparative Analysis, edited by R. R. Nelson. Oxford: Oxford University Press.

Kim, Linsu. 1993. National System of Industrial Innovation: Dynamics of Capability Building in Korea. In National Innovation Systems: A Comparative Analysis, edited by R. R. Nelson. Oxford: Oxford University Press.

Lall, Sanjaya. 1996. Learning from the Asian Tigers: Studies in Technology and Industrial Policy. New York: St. Martin's Press.

Loo, Becky P.Y. 2002. The Textile and Clothing Industries Under the Fifth Kondratieff Wave: Some Insights From the Case of Hong Kong. World Development 30 (5):847-872.

Mahmood, Ishtiaq P., and Jasjit Singh. 2003. Technological Dynamism in Asia. Research Policy 32:1031-1054.

Nelson, Richard R. 1993. National Innovation Systems: A Comparative Analysis. New York: Oxford University Press.

Organisation for Economic Co-operation and Development. 1999. Managing National Innovation Systems. Paris: Organisation for Economic Co-operation and Development.

Tao, Z, and Y. C. R. Wong. 2002. Hong Kong: From an Industrialized City to a Center of Manufacturing-Related Services. In Hong Kong University, HKIEBS Working Papers. Hong Kong.

Thompson, E. R. 2003. Technology Transfer to China by Hong Kong's Cross-Border Garment Firms. The Developing Economies XLI-1 (March):88-111.

Wong, Poh-Kam. 1996. National Systems of Innovation: The Case of Singapore. Seoul: Science and Technology Policy Institute.

. 2003. From Using to Creating Technology: The Evolution of Singapore's National Innovation System and the Changing Role of Public Policy. In Competitiveness, FDI and Technological Activity in East Asia, edited by S. Lall and S. u. Urata. Cheltenham, UK ; Northampton, MA, USA: E. Elgar Pub.

Wong, Siu-lun. 1988. Emigrant Entrepreneurs: Shanghai Industrialists in Hong Kong. Hong Kong; New York: Oxford University Press. 
Table 1: $\quad$ Hong Kong’s R\&D Expenditure by Sector, 1995 to 2002

\begin{tabular}{|c|c|c|c|c|c|c|c|c|}
\hline Year/Sector & 1995 & 1996 & 1997 & $\mathbf{1 9 9 8}$ & $\mathbf{1 9 9 9}$ & $\mathbf{2 0 0 0}$ & $\mathbf{2 0 0 1}$ & $\mathbf{2 0 0 2}$ \\
\hline $\boldsymbol{B E R D}^{\mathrm{H}}$ & $0.12 \%^{\mathrm{a}}$ & $0.14 \%^{\mathrm{a}}$ & $0.11 \%^{\mathrm{a}}$ & $0.12 \%^{\mathrm{b}}$ & $0.11 \%^{\mathrm{b}}$ & $0.09 \%^{\mathrm{b}}$ & $0.16 \%^{\mathrm{b}}$ & $0.20 \%^{\mathrm{b}}$ \\
\hline HERD & $0.25 \%^{\mathrm{d}}$ & $0.27 \%^{\mathrm{d}}$ & $0.29 \%^{\mathrm{d}}$ & $0.31 \%^{\mathrm{b}}$ & $0.35 \%^{\mathrm{b}}$ & $0.38 \%^{\mathrm{b}}$ & $0.38 \%^{\mathrm{b}}$ & $0.38 \%^{\mathrm{b}}$ \\
\hline GOVERD & $0.01 \%^{\mathrm{c}}$ & $0.01 \%^{\mathrm{c}}$ & $0.01 \%^{\mathrm{c}}$ & $0.01 \%^{\mathrm{b}}$ & $0.01 \%^{\mathrm{b}}$ & $0.01 \%^{\mathrm{b}}$ & $0.01 \%^{\mathrm{b}}$ & $0.02 \%^{\mathrm{b}}$ \\
\hline $\begin{array}{c}\text { Total } \\
(\boldsymbol{G E R D})\end{array}$ & $\mathbf{0 . 3 8 \%}$ & $\mathbf{0 . 4 2 \%}$ & $\mathbf{0 . 4 1 \%}$ & $\mathbf{0 . 4 4} \%^{\mathrm{b}}$ & $\mathbf{0 . 4 7} \%^{\mathrm{b}}$ & $\mathbf{0 . 4 8} \%^{\mathrm{b}}$ & $\mathbf{0 . 5 5 \% ^ { \mathrm { b } }}$ & $\mathbf{0 . 6 0}^{\mathrm{b}}$ \\
\hline
\end{tabular}

a Figures from "Feature Article”, published in the Hong Kong Monthly Digest of Statistics, July 2001, p. FC5

${ }^{\mathrm{b}}$ Figures from Table 2, "Feature Article, 'Research and Development Statistics of Hong Kong, 1998 2002’”, published in the Hong Kong Monthly Digest of Statistics, May 2004, p. FD4.

${ }^{\mathrm{c}}$ Estimates based on 1998 and onward figures, Census and Statistics Department

${ }^{\mathrm{d}}$ Percentage figures calculated from "Feature Article, 'Government Funding of R\&D, Innovation and Technology Upgrading, 1995/96 - 2001/02'”, published in the Hong Kong Monthly Digest of Statistics, July 2003, p. FD9. 
Table 2: $\quad$ Number of Patent Applications in Hong Kong by type of patent application, 1991 - 2001

\begin{tabular}{|c|c|c|c|c|c|c|c|c|c|c|c|c|}
\hline $\begin{array}{c}\text { Type of Patent } \\
\text { Application/Year }\end{array}$ & 1991 & 1992 & 1993 & 1994 & 1995 & 1996 & 1997 & 1998 & 1999 & 2000 & 2001 & 2002 \\
\hline $\begin{array}{c}\text { Standard Patent } \\
\text { Application }\end{array}$ & & & & & & & $\begin{array}{l}1,179 \\
(49 \%)\end{array}$ & $\begin{array}{c}19,139^{\mathrm{a}} \\
(99 \%)\end{array}$ & $\begin{array}{l}6,040 \\
(97 \%)\end{array}$ & $\begin{array}{l}8.295 \\
(97 \%)\end{array}$ & $\begin{array}{l}8,914 \\
(97 \%)\end{array}$ & $\begin{array}{l}9,130 \\
(97 \%)\end{array}$ \\
\hline $\begin{array}{c}\text { Short-term } \\
\text { Patent } \\
\text { Application }\end{array}$ & & & & & & & $\begin{array}{c}30 \\
(1 \%)\end{array}$ & $\begin{array}{c}113 \\
(1 \%)\end{array}$ & $\begin{array}{c}175 \\
(3 \%)\end{array}$ & $\begin{array}{c}274 \\
(3 \%)\end{array}$ & $\begin{array}{c}312 \\
(3 \%)\end{array}$ & $\begin{array}{c}333 \\
(3 \%)\end{array}$ \\
\hline $\begin{array}{c}\text { Patent } \\
\text { applications } \\
\text { filed under } \\
\text { repealed } \\
\text { Registration of } \\
\text { Patents } \\
\text { Ordinance } \\
\end{array}$ & $\begin{array}{c}1,092 \\
(100 \%)\end{array}$ & $\begin{array}{c}1,259 \\
(100 \%)\end{array}$ & $\begin{array}{c}1,195 \\
(100 \%)\end{array}$ & $\begin{array}{c}1,640 \\
(100 \%)\end{array}$ & $\begin{array}{c}1,961 \\
(100 \%)\end{array}$ & $\begin{array}{c}2,100 \\
(100 \%)\end{array}$ & $\begin{array}{l}1,215 \\
(50 \%)\end{array}$ & & & & & \\
\hline Total & 1,092 & 1,259 & 1,195 & 1,640 & 1,961 & 2,100 & 2,424 & 19,252 & 6,215 & 8,569 & 9,226 & 9,463 \\
\hline
\end{tabular}

a The surge in standard patent applications in 1998 was due mainly to the large number of applications filed under the Patent (Transitional Arrangements) Rules

Figures in brackets represent the percentages of total.

Source: “Feature Article, 'Patent Statistics for Hong Kong, 1991-2001'”, published in the Hong Kong Monthly Digest of Statistics, January 2003, p. FC6. 
Table 3: $\quad$ Research Output: Number of Studies Published by Eight Higher

Education Institutions, by Broad Subject Area

\begin{tabular}{|c|c|c|c|c|c|c|c|}
\hline $\begin{array}{c}\text { Broad } \\
\text { Subject } \\
\text { Area/Year }\end{array}$ & $\mathbf{1 9 9 3 / 1 9 9 4}$ & $\mathbf{1 9 9 6 / 1 9 9 7}$ & $\mathbf{1 9 9 7 / 1 9 9 8}$ & $\mathbf{1 9 9 8 / 1 9 9 9}$ & $\mathbf{1 9 9 9 / 2 0 0 0}$ & $\mathbf{2 0 0 0 / 2 0 0 1}$ & $\mathbf{2 0 0 1 / 2 0 0 2}$ \\
\hline $\begin{array}{c}\text { Biology and } \\
\text { Medicine }\end{array}$ & 3,070 & 3,959 & 4,722 & 4,900 & 5,336 & 6,149 & 6,529 \\
\hline $\begin{array}{c}\text { Physical } \\
\text { Sciences }\end{array}$ & 1,092 & 1,749 & 1,894 & 1,910 & 1,951 & 2,649 & 2,764 \\
\hline Engineering & 2,495 & 4,056 & 4,608 & 4,829 & 5,234 & 6,644 & 6,309 \\
\hline $\begin{array}{c}\text { Humanities, } \\
\text { social } \\
\text { sciences, } \\
\text { and } \\
\text { business } \\
\text { studies }\end{array}$ & 6,484 & 8,811 & 10,366 & 9,247 & 10,570 & 11,238 & 11,494 \\
\hline $\begin{array}{c}\text { All subject } \\
\text { areas }\end{array}$ & $\mathbf{1 3 , 1 4 1}$ & $\mathbf{1 8 , 5 7 5}$ & $\mathbf{2 1 , 5 8 9}$ & $\mathbf{2 0 , 8 8 6}$ & $\mathbf{2 3 , 0 9 1}$ & $\mathbf{2 6 , 6 8 0}$ & $\mathbf{2 6 , 9 9 6}$ \\
\hline
\end{tabular}

Source: Table 6.7, Hong Kong Annual Digest of Statistics, 2003, p. 128

\footnotetext{
${ }^{1}$ The terms 'innovation system' and 'systems of innovation' are used interchangeably in this paper and refer to identical phenomena without distinction.

${ }^{2}$ Although Hong Kong is, from a geographical and political point of view, unequivocally part of China (as a Special Administrative Region or SAR), economically and constitutionally it is sufficiently distinct (from the People's Republic of China) to be considered, from a conceptual standpoint, a 'national' innovation system solely for analytical purposes (one country, two systems). Therefore, any and all references to 'Hong Kong', 'Hong Kong SAR', 'HK', or 'HKSAR' in this report denote, in full and without exception, 'The Hong Kong Special Administrative Region of the People’s Republic of China'.

${ }^{3}$ The patent system in Hong Kong was previously based on the Registration of Patents Ordinance. This was essentially a re-registration system based on a first registration taking effect in the United Kingdom. With the transfer of Hong Kong's sovereignty to the PRC on 1 July 1997, Hong Kong has localised its patent law and has introduced its own patent system. The Patents Ordinance came into force on 27 June 1997. The Ordinance provides for the establishment of an independent patents regime and the grading of standard patents and short-term patents.

${ }^{4}$ Research output categories generally include: scholarly books and monographs; journal articles, book chapters and other published papers; conference and working papers; works of fiction, consulting reports, and case studies; reviews, translations, and other written outputs; editorships and high-level service external to the institution; and other creative work not listed above.

${ }^{5}$ ASTRI's current research foci are photonic technologies, integrated circuit design, Internet software, wireless communications and biotechnology.

${ }^{6}$ Its largest target sectors are electronics, information technology and telecommunications, biotechnology, and precision engineering.
} 


\footnotetext{
${ }^{7}$ The ARF has HK\$750 million in capital. In November 1988, two private-sector venture capital firms were appointed to manage the investment of the ARF.

${ }^{8}$ An often-used diagram to represent a country's innovation system is provided by the OECD (1999: 23). In such a schematic, inputs into the innovation system are characterized as education, product markets, factor markets, and communication infrastructures. The outputs are represented by country performance (both $R \& D$ performance and overall performance) measured in terms of growth, job creation, and competitiveness.

${ }^{9}$ Chiu and Wong (2001) claim that if formal R\&D investments had been channeled to the electronics sector (an existing industry in which Hong Kong firms had inherent capabilities and skills), it is likely that the industry would have been able to maintain its global position of leadership more effectively.

${ }^{10}$ Since such quotas will be phased out as part of WTO arrangements in 2005, it is expected that Hong Kong garment firms will increasingly need to upgrade their capabilities for design, branding, and networking.

${ }^{11}$ For a study that discusses the low level of patenting in Hong Kong as compared with that in other East Asian tiger economies, see Mahmood and Singh (2003).

12 The region known as the Pearl River Delta Region (PRD) is found along the estuary of the Pearl River in Guangdong Province, comprising 50,000 sq. km., a population of roughly 40 million, with a GDP of US\$100 million (excluding Hong Kong and Macau).

${ }^{13}$ This section is from: HKSAR, Innovation and Technology Commission 2004.
} 